See Article page e215.

\section{Commentary: The unacceptable aortic risk with fluoroquinolone exposure in Marfan syndrome}

\author{
Leora B. Balsam, MD, ${ }^{\mathrm{a}}$ and \\ William D. Hoffman, MD ${ }^{\mathrm{b}}$
}

The harmful effect of fluoroquinolone antibiotics on the extracellular matrix was first brought into focus by the US Food and Drug Administration (FDA) in 2008 with a black box warning regarding increased risk of tendonitis and rupture after recent use. Because extracellular matrix dysregulation is a key event in the development of aortic aneurysm and aortic dissection (AAD), it was also hypothesized that fluoroquinolones could increase the risk of AAD. This was supported by several population-based studies that found an association between recent fluoroquinolone use and the development of AAD. ${ }^{1-3}$ The FDA issued 2 follow-up safety announcements. The first of these announcements, published in 2016, recommended avoidance of fluoroquinolones for acute bacterial sinusitis, bronchitis, and uncomplicated urinary tract infection, because the risk likely outweighed the benefit. At the time, the fluoroquinolones were one of the most commonly prescribed antibiotic classes, with nearly 30 million outpatient prescriptions filled each year in the United States. ${ }^{4}$ The second FDA announcement, in 2018, recommended avoiding fluoroquinolones in patients with aortic aneurysms or patients at risk for AAD, including those with heritable aortopathies.

The fact that it took nearly 40 years on the commercial market to identify and acknowledge this ultimately measurable safety signal is remarkable. And even now, despite these warnings, the shift away from fluoroquinolone use has been slow. Clinicians have continued to prescribe them in uncomplicated infections, perhaps due to their

\footnotetext{
From the ${ }^{\mathrm{a} D i v i s i o n}$ of Cardiac Surgery and ${ }^{\mathrm{b}}$ Department of Anesthesiology and Perioperative Medicine, UMass Memorial Medical Center, Worcester, Mass.

Disclosures: The authors reported no conflicts of interest.

The Journal policy requires editors and reviewers to disclose conflicts of interest and to decline handling or reviewing manuscripts for which they may have a conflict of interest. The editors and reviewers of this article have no conflicts of interest.

Received for publication Sept 27, 2020; revisions received Sept 27, 2020; accepted for publication Sept 28, 2020; available ahead of print Oct 5, 2020.

Address for reprints: Leora B. Balsam, MD, Division of Cardiac Surgery, UMass Memorial Medical Center, University Campus, 55 Lake Ave North, Worcester, MA 01655 (E-mail: leora.balsam@umassmemorial.org).

J Thorac Cardiovasc Surg 2022;163:e227-8

$0022-5223 / \$ 36.00$

Copyright (C) 2020 by The American Association for Thoracic Surgery

http://dx.doi.org/10.1016/j.jtcvs.2020.09.115
}

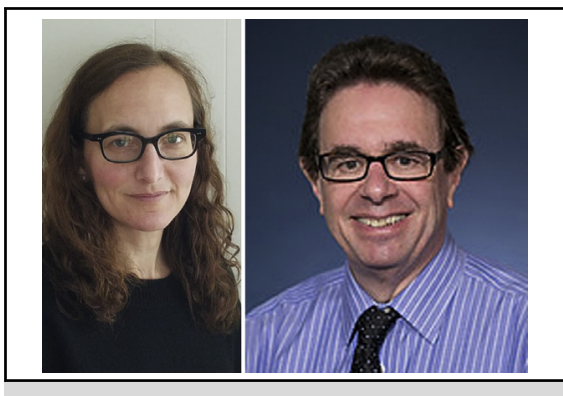

Leora B. Balsam, MD, and William D. Hoffman, MD

$$
\begin{aligned}
& \text { CENTRAL MESSAGE } \\
& \text { Mounting evidence suggests that } \\
& \text { fluoroquinolones should be } \\
& \text { avoided in patients with aortop- } \\
& \text { athy. A new study links cipro- } \\
& \text { floxacin exposure to aneurysm } \\
& \text { formation and dissection in a } \\
& \text { Marfan syndrome mouse model. }
\end{aligned}
$$

broad antimicrobial spectrum and excellent oral bioavailability. Recent data show that even at-risk patients with preexisting $\mathrm{AAD}$ are treated with fluoroquinolones at an alarming rate. ${ }^{5}$ Among 99,818 unique hospitalized patients with AAD recorded in an administrative database between 2009 and 2015, Frankel and colleagues ${ }^{5}$ found that $20 \%$ received fluoroquinolones. A subgroup analysis found that $14 \%$ of Marfan syndrome patients with AAD received fluoroquinolones.

LeMaire and colleagues ${ }^{6}$ at Baylor have been important voices in the story of fluoroquinolones and aortic disease. Their experimental work has identified potential mechanisms for the increased risk of AAD with fluoroquinolone use in at-risk patients. In their article in this issue of the Journal, they focus specifically on the relationship between fluoroquinolone administration and Marfan syndrome using fibrillin-1 mutant mice. ${ }^{6}$ They report that ciprofloxacintreated Marfan mice had accelerated aortic enlargement and increased incidence of aortic dissection and rupture. Aortic dissection occurred in $47 \%$ of the drug-treated mice, compared with $25 \%$ of the vehicle-treated mice, and aortic rupture occurred in $25 \%$ of drug-treated mice compared with $5 \%$ of vehicle-treated mice. Histologically, the authors found greater elastic fiber destruction, increased levels of matrix metalloproteinases, and greater numbers of 
apoptotic cells in the aortic walls of fluoroquinolone-treated Marfan mice compared with the vehicle-treated mice. This study is a logical extension of the authors' previous experimental work with mice with sporadic AAD, in which they demonstrated that fluoroquinolone treatment increased destruction of the aortic wall and increased the occurrence of rupture and premature death.

There are some limitations to the study that the authors acknowledge. Only one fluoroquinolone was studied (ciprofloxacin), and dose-related effects were not investigated. Although the authors chose a clinically relevant dose, they administered it over the course of 28 days, which is longer than the typical clinical treatment course. The specific mouse fibrillin-1 mutation studied might not recapitulate the behavior of all fibrillin-1 mutations in human Marfan disease. Despite these limitations, this work links cause (fluoroquinolones) and effect (AAD) in a way that population-based studies have been unable to do. The authors' conclusion that these drugs should be avoided in patients with Marfan syndrome is appropriate.

\section{References}

1. Daneman N, Lu H, Redelmeier DA. Fluoroquinolones and collagen-associated severe adverse events: a longitudinal cohort study. BMJ Open. 2015;5:e010077.

2. Lee CC, Lee MTG, Chen YS, Lee SH, Chen YS, Chen SC, et al. Risk of aortic dissection and aortic aneurysm in patients taking oral fluoroquinolone. JAMA Intern Med. 2015;175:1839-47.

3. Pasternak B, Inghammar M, Svanström H. Fluoroquinolone use and risk of aortic aneurysm and dissection: Nationwide cohort study. BMJ. 2018;360:k678

4. Hicks LA, Bartoces MG, Roberts RM, Suda KJ, Hunkler RJ, Taylor TH Jr, et al. US outpatient antibiotic prescribing variation according to geography, patient population, and provider specialty in 2011. Clin Infect Dis. 2015;60:1308-16.

5. Frankel WC, Trautner BW, Spiegelman A, Grigoryan L, LeMaire SA. Patients at risk for aortic rupture often exposed to fluoroquinolones during hospitalization. Antimicrob Agents Chemother. 2019;63:e0712-8.

6. LeMaire SA, Zhang L, Zhange NS, Luo W, Barrish JP, Zhang Q, et al. Ciprofloxacin accelerates aortic enlargement and promotes dissection and rupture in Marfan mice. J Thorac Cardiovasc Surg. 2022;163:e215-26.

7. LeMaire SA, Zhang L, Luo W, Ren P, Azares AR, Wang Y, et al. Effect of ciprofloxacin on susceptibility to aortic dissection and rupture in mice. JAMA Surg. 2018;153:e181804
See Article page e215.

\section{Commentary: Danger of fluoroquinolones in Marfan syndrome}

\author{
Ming-Sing Si, MD
}

Fluoroquinolones are one of the most prescribed antibiotics and have been linked to the development of tendon rupture and nerve injury, earning them a black box warning from the US Food and Drug Administration. ${ }^{1}$ Concerningly, previous clinical observational studies also have identified an association between fluoroquinolone use and the development of

From the Section of Pediatric Cardiovascular Surgery, Department of Cardiac Surgery, University of Michigan, Ann Arbor, Mich.

Disclosures: The author reported no conflicts of interest.

The Journal policy requires editors and reviewers to disclose conflicts of interest and to decline handling or reviewing manuscripts for which they may have a conflict of interest. The editors and reviewers of this article have no conflicts of interest.

Received for publication Oct 13, 2020; revisions received Oct 13, 2020; accepted for publication Oct 15, 2020; available ahead of print Oct 22, 2020.

Address for reprints: Ming-Sing Si, MD, 11-735, C.S. Mott Children's Hospital, SPC 4204, 1540 E. Hospital Dr, Ann Arbor, MI 48109-4204 (E-mail: mingsing@umich. edu).

J Thorac Cardiovasc Surg 2022;163:e228-9

$0022-5223 / \$ 36.00$

Copyright $₫ 2020$ Published by Elsevier Inc. on behalf of The American Association for Thoracic Surgery

http://dx.doi.org/10.1016/j.jtcvs.2020.10.057
Check for updates

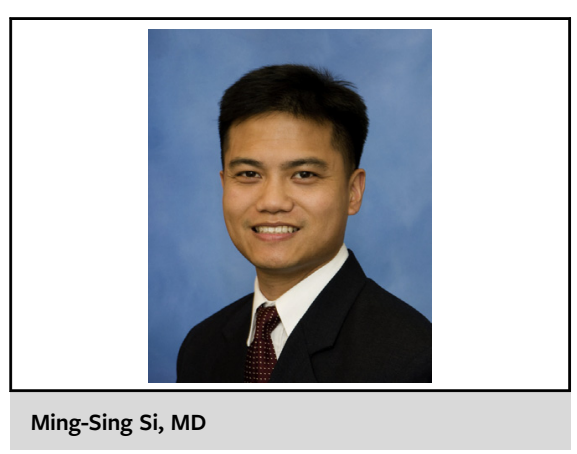

CENTRAL MESSAGE

New data using a murine model of Marfan syndrome reveal that ciprofloxacin can exacerbate the aortic phenotype.

aortic dissection and aortic aneurysm., ${ }^{2,3}$ LeMaire and colleagues $^{4}$ previously demonstrated that ciprofloxacin increased the risk of aortic dissection and rupture in a mouse model of moderate, sporadic aortic aneurysm and dissection. In this issue of the Journal, LeMaire and colleagues ${ }^{5}$ extend 